\title{
Eğitim Fakültesi Meslek Bilgisi Derslerinin Sıralama Yargıları Kanunuyla Ölçeklenmesi
}

\section{Scaling Pedagogy Courses Faculty of Education With Rank- Order Judgments}

\author{
Seher YALÇIN *
}

Asiye ŞENGÜL AVŞAR **

$\ddot{O ̈ z}$

$\mathrm{Bu}$ araştırmanın amacı, eğitim fakültesi dördüncü sınıf öğrencilerinin aldıkları meslek bilgisi derslerinin sıralama yargıları kanunuyla ölçeklenmesidir. Araştırma 2012-2013 eğitim öğretim yılında Ankara Üniversitesi Eğitim Bilimleri Fakültesi ve Recep Tayyip Erdoğan Üniversitesi Eğitim Fakültesi'nde eğitim gören toplam 313 son sınıf öğrencisi ile yürütülmüştür. Araştırmaya katılan öğrencilerin \%69'u kadın, \%31’i erkektir. Araştırmacılar tarafindan geliştirilen "Meslek Bilgisi Derslerini Değerlendirme Formu" ölçekleme işlemi için kullanılmıştır. Yapılan ölçekleme işlemi sonunda öğrencilerin en önemli gördükleri ders "Okul Deneyimi”" olarak bulunmuştur. Bu dersi sırasıyla "Sınıf Yönetimi”, "Öğretim İlke ve Yöntemleri”, "Eğitim Psikolojisi", "Öğretim Teknolojileri ve Materyal Tasarımı", "Ölçme ve Değerlendirme" ve "Özel Eğitim” dersleri takip etmiştir.

Anahtar Kelimeler: meslek bilgisi dersleri, ölçekleme, sıralama yargıları kanunu.

\begin{abstract}
The aim of this research is to scale pedagogy courses taken by senior class students year students in faculty of education with rank-order judgment. This research was conducted with 313 fourth year students in total studying in Ankara University Faculty of Educational Sciences and Recep Tayyip Erdoğan University Faculty of Education in 2012-2013 academic year. 69 percent of the participants were woman and \%31 of them were man. Form for Evaluating Pedagogy Courses developed by the researchers was used for scaling. After scaling, it is found that the most important course is "school experience" according to students. The others are "classroom management, teaching methods and approaches, educational psychology, educational technologies and material development, measurement and evaluation and special education" respectively.
\end{abstract}

Key Words: pedagogy courses, scaling, rank-order judgments.

\section{GíRIŞ}

Nitelikli insan gücüne duyulan ihtiyaç, nitelikli eğitim kurumlarıyla sağlanabilir. Eğitimin niteliğini etkileyen pek çok faktör vardır ve bu faktörlerin en önemlilerinden biri de öğretmenlerdir (S1lay ve Gök, 2004). Öğretmenler; araştırma çalışmalarından etkilenebilen, araştırma sonucu geliştirilen eğitim politikalarını uygulamaya koyan ve bu politikaları etkileyebilen kişi konumundadırlar (Varış, 1973). Bu nedenle öğretmenlerin nitelikli bir öğretmen olabilmek yönünde tüm yeterlilikleri kazanmaları gerekmektedir. Nitelikli bir öğretmen olabilmek için, eğitim fakültelerinde öğrenim gören öğretmen adayları genel kültür, konu alanı bilgisi ve ögretmenlik meslek bilgisi derslerini almak zorundadırlar. Bu kapsamda öğretmenlik meslek bilgisi dersleri, öğretmenlik mesleğine ilişkin özel davranışları kazandırmayı amaçlar. Böylece öğretmen adayı, öğretmenlik mesleğinin gerektirdiği davranışları kazanarak, öğretiminde görevli olduğu alanın eğitsel-öğretimsel sürecine katkıda bulunabilecektir (Küçükahmet, 1993). Şişman (2001), öğretme ve öğrenme sürecinde öğretmene gerekli olan bilgi, beceri ve yeterliklerin hizmete başlamadan kazanılmasının gerektiğini ifade etmektedir. Öğretmen adaylarının profesyonel gelişimlerini tamamlayarak

\footnotetext{
* Araş. Gör., Ankara Üniversitesi, Eğitim Bilimleri Fakültesi, Ankara-Türkiye, yalcins@ ankara.edu.tr

** Araş. Gör., Recep Tayyip Erdoğan Üniversitesi, Eğitim Fakültesi, Rize-Türkiye, asiye.sengul@ erdogan.edu.tr
} 
nitelikli birer öğretmen olmalarında eğitim fakültelerinde uygulanan programların, özellikle meslek bilgisi derslerinin rolü büyüktür. Ayrıca 1973 yılında yürürlüğe giren 1739 sayılı Milli Eğitim Temel Yasasının 43. maddesinde öğretmenlik mesleğinin bir uzmanlık mesleği olduğu vurgulanarak "Öğretmenlik mesleğine hazırlık; genel kültür, özel alan eğitimi ve pedagojik formasyonla sağlanır.” ifadesi yer almaktadır (Yükseköğretim Kurulu [YÖK], 2007).

Meslek bilgisi dersleri, öğretmen adaylarına alan bilgisi derslerinden edinmiş oldukları bilgileri, öğrencilerin gelişim özelliklerini de dikkate alarak, nasıl öğretecekleri ve öğretimin yapılacağ1 ortamın düzenlenmesi gibi konulara yönelik bilgiler verir (YÖK, 2007). Küçükahmet (2007), öğretmen yetiştirme programlarının öğretmenlik mesleği kazandıran programlar olduğunu, bu sebeple öğretmenlik meslek bilgisi derslerinin titizlikle belirlenmesi gerektiğini vurgulamıştır.

Eğitim fakültelerinin 1998 yılında Yüksek Öğretim Kurumu (YÖK) tarafından yeniden yapılandırılması ve akreditasyonu sonucunda, öğretmenlik meslek bilgisi ders programları yeniden düzenlenmiştir. Bu düzenleme ile öğretmenlik meslek bilgisi derslerinin toplam kredisi 21'den 36'ya, ders saatleri ise toplam 48 saate yükseltilmiştir. Daha sonra uygulanan bu programlar gerek Milli Eğitim Bakanlığının İlköğretim programlarında yapmış olduğu değişiklikler sebebiyle, gerekse programların aksayan yönlerinin düzeltilmesi ve programların geliştirilmesi amacıyla 2006 yılında güncellenmiştir (Taşkın ve Hacıömeroğlu, 2010).

Nitelikli eğitim ancak nitelikli öğretmenler ile verilebilir. Eğitim fakülteleri nitelikli, mesleki donanımları olan öğretmen adayları yetiştirmelidir. Meslek bilgisi dersleri, öğretmen adaylarına, alan bilgisi derslerinden edinmiş oldukları bilgileri, öğrencilerin gelişim özelliklerini de dikkate alarak, nasıl öğretecekleri ve öğretimin yapılacağı ortamın düzenlenmesi gibi konulara yönelik bilgiler verdiğinden bu derslerin önemi dikkat çekicidir.

$\mathrm{Bu}$ derslerin öğrencilere göre önem düzeyinin belirlenmesinde, öğrencilerin her bir uyarıcıyı karşılaştırarak verdiği değerlerin bir standarda dönüştürülmesinde, yani uyarıcılara verilen sıralama yargılarından elde edilen oranlardan ölçek değerlerinin elde edilmesinde ölçekleme işlemi yapılır. "Gözlemlerden ölçülere geçiş"in temel kurallarını ve başlıca yöntemlerini ortaya koyan, nitel ayrımları gösteren gözlemlerden nicel ayrımları gösteren ölçülere geçişte önemli bir çalışma alanı, ölçeklemedir (Anıl ve Güler, 2006). Ölçekleme "denek tepkilerine ve yargıcı kararlarına dayalı yaklaşımlar" olmak üzere iki grupta toplanmaktadır. Yargıcı kararlarına dayalı yaklaşım, uyarıcıları uzman ya da bilirkişi yargılarına göre belirli bir boyutta ölçeklemeyi içerir ve her bir uyarıcının uyarıcılık derecesi belli bir yöntemle (sıralama, sınıflama, ikili karşılaştırma gibi) belirlenir (Stevens, 1946: Akt. Turgut ve Baykul, 1992). Sıralama yargıları kanunuyla ölçekleme ise uyarıcıların belirli bir nitelikte büyükten küçüğe ya da küçükten büyüğe doğru sıralanması ve her birine siradaki yerine göre bir sıra sayısı verilmesidir. Bu yöntem gözlemciyi, uyarıcılar arasında mümkün olan en büyük sayıda ayrımı yapmaya zorlar ve gözlemci bu ayrımı yapabildiği durumlarda ölçeğin geçerliği yüksek olur.

Yapılan bu çalışma ile öğretmen adaylarının aldıkları meslek bilgisi derslerini en önemli görme durumlarının belirlenmesi amaçlanmıştır. Yapılan ölçekleme işlemi sonunda öğretmen adaylarının önem sıralamasında sonlarda gördükleri meslek derslerinin belirlenmesi, bu doğrultuda öneriler geliştirilmesine fırsat verebileceğinden önem taşımaktadır. $\mathrm{Bu}$ bağlamda yapılan bu çalışma öğretmen yetiştirme politikaların belirlenmesinde de önem taşımaktadır.

Konuyla ilgili araştırmalara (Şirin ve Cesur, 2008; Şişman ve Acat, 2003; Taşkın ve Hacıömeroğlu, 2010) bakıldığında, öğretmen adaylarının eğitim fakülteleri programlarında 
yer alan meslek bilgisi derslerine ilişkin bakış açılarının ağırlıklı olarak "Okul Deneyimi" ve "Öğretmenlik Uygulaması" dersleri dikkate alınarak incelendiğini göstermektedir. Bazı araştırmalarda (Ekici, 2008; Taşkın ve Haciömeroğlu, 2010; Yüksel, 2009) ise öğrencilerin meslek bilgisi derslerine yönelik görüşleri alınmıştır. Bununla beraber, öğretmen adaylarının meslek bilgisi derslerine ilişkin bakış açılarını bütün olarak inceleyen çalışmaların sınırlı sayıda olduğu anlaşılmaktadır. Ölçekleme çalışmaları ile ilgili Türkiye'de yapılan çalışmalara bakıldığında ise farklı konularda pek çok ölçekleme çalışmasının yapıldığ görülmüştür. Bu çalışmalar incelendiğinde, sıralama yargıları kanunları yöntemiyle yapılan az sayıda çalışma (Bal, 2011) olduğu, ikili karşılaştırmalar yöntemiyle yapılan ölçekleme çalışmalarının (Altun ve Gelbal, 2014; Anıl ve Güler, 2006; Bülbül ve Acar, 2012; Kara ve Gelbal, 2013; Kart ve Gelbal, 2014; Nartgün, 2006; Özer ve Acar, 2011; Polat ve Göksel, 2014) çoğunlukta olduğu görülmüştür. Ayrıca farklı ölçekleme yaklaşımlarının karşılaştırıldığı çalışmalar da (Acar Güvendir ve Özer Özkan, 2013; Albayrak ve Gelbal, 2012; Öztürk, Özdemir ve Gelbal, 2011) yapılmıştır. $\mathrm{Bu}$ araştırmanın sıralama yargıları kanunları ile yapılan bir araştırma olması, bu konuda yapılan az sayıda araştırma olduğundan ayrıca önem taşımaktadır. Bu nedenlerle, eğitim fakültesi dördüncü sınıf öğrencilerinin, YÖK tarafından belirlenen öğretmenlik meslek bilgisi derslerini, öğretmen olduklarında önemli olma durumlarına göre sıralatarak ölçekleme yapılmasına gereklilik görülmüştür.

\section{Araştırmanın Amact}

$\mathrm{Bu}$ çalışmanın amacı, eğitim fakültesi dördüncü sınıf öğrencilerinin sekizinci eğitim-öğretim dönemine kadar aldıkları meslek bilgisi derslerinin hangisini daha önemli gördüklerinin belirlenmesidir. Bu genel amaç doğrultusunda aşağıdaki sorulara yanıt aranmıştır.

Sıralama yargıları kanunuyla ölçekleme yönteminden;

1. Tüm grup için elde edilen ölçek değerleri nedir?

2. Kadın öğrenciler için elde edilen ölçek değerleri nedir?

3. Erkek öğrenciler için elde edilen ölçek değerleri nedir?

4. Ankara Üniversitesi öğrencileri için elde edilen ölçek değerleri nedir?

5. Recep Tayyip Erdoğan Üniversitesi öğrencileri için elde edilen ölçek değerleri nedir?

\section{YÖNTEM}

Eğitim fakültesi dördüncü sınıf öğrencilerinin meslek bilgisi derslerinin hangisini daha önemli gördüklerinin sıralama yargıları kanunuyla ölçeklenmesinin amaçlandığı bu araştırma, var olan durumu betimlemeyi amaçladığından tarama modelindedir (Karasar, 2007).

\section{Çalışma Grubu}

Yapılan bu araştırmanın çalışma grubunu 2012-2013 eğitim-öğretim yılında Ankara Üniversitesi Eğitim Bilimleri Fakültesi [Sınıf Öğretmenliği (SÖ), Bilgisayar ve Öğretim Teknolojileri Öğretmenliği (BÖTE), Okul Öncesi Öğretmenliği (OÖÖ), Sosyal Bilgiler Öğretmenliği (SBÖ) ve Zihin Engelliler Öğretmenliği (ZEÖ)] ve Recep Tayyip Erdoğan Üniversitesi Eğitim Fakültesi'nin çeşitli bölümlerinde [İlköğretim Matematik Öğretmenliği (İMÖ), Sınıf Öğretmenliği (SÖ)] eğitim gören toplam 313 öğrenci oluşturmaktadır. Tablo 1'de uygulamaya katılan öğrencilere ait betimsel istatistikler yer almaktadır. 
Tablo 1. Uygulamaya Katılan Ö̈̆rencilere Ait Frekans ve Yüzdeler

\begin{tabular}{|c|c|c|c|c|c|}
\hline & \multirow{3}{*}{ Bölüm } & \multicolumn{4}{|c|}{ Cinsiyet } \\
\hline & & \multicolumn{2}{|c|}{ Kadın } & \multicolumn{2}{|c|}{ Erkek } \\
\hline & & $\mathrm{f}$ & $\%$ & $\mathrm{f}$ & $\%$ \\
\hline \multirow{6}{*}{ Ankara Üniversitesi } & SÖ & 31 & 91,2 & 3 & 8.8 \\
\hline & BÖTE & 16 & 50 & 16 & 50 \\
\hline & OÖÖ & 40 & 95,2 & 2 & 4,8 \\
\hline & SBÖ & 9 & 60 & 6 & 40 \\
\hline & ZEÖ & 14 & 50 & 14 & 50 \\
\hline & Toplam & 110 & 72,8 & 41 & 27,2 \\
\hline Recep Tayyip Erdoğan & İMÖ & 19 & 63.3 & 11 & 36.7 \\
\hline \multirow[t]{2}{*}{ Üniversitesi } & SÖ & 87 & 65.9 & 45 & 34.1 \\
\hline & Toplam & 106 & 65,4 & 56 & 34,6 \\
\hline Genel Toplam & & 216 & - & 97 & - \\
\hline
\end{tabular}

Tablo 1'de görüldüğü gibi, her iki üniversiteden de yakın sayıda öğrenciye uygulama yapılmıştır. Katılımcıların çoğunluğu kadınlardan oluşmaktadır.

\section{Veri Toplama Araçlart}

$\mathrm{Bu}$ araştırmada öğrencilerin aldıkları meslek bilgisi derslerini sıralama yargıları kanunuyla ölçeklemek için araştırmacılar tarafından "Meslek Bilgisi Derslerini Değerlendirme Formu" geliştirilmiştir. $\mathrm{Bu}$ form oluşturulurken YÖK tarafindan açıklanan lisans meslek bilgisi derslerinin hangi bölümlerde, hangi dönemde öğrencilerin dersleri aldıkları dikkate alınmıştır. Bu bilgiler Tablo 2'de gösterilmiştir.

Tablo 2. Bölümlere Göre Ders Programında Yer Alan Meslek Bilgisi Derslerini Öğrencilerin Aldıkları Dönemler

\begin{tabular}{lcccccr}
\hline \multirow{2}{*}{ Dersin Adı } & \multicolumn{5}{c}{ Bölümlere Göre Derslerin Dönemleri } \\
\cline { 2 - 7 } & İMÖ & ZEÖ & BÖTE & OÖÖ & SBÖ & SÖ \\
\hline A. Eğitim Psikolojisi & 2 & 2 & 2 & 2 & 3 & 2 \\
B. Öğretim İlke ve Yöntemleri & 3 & 3 & 3 & 3 & 4 & 3 \\
C. Öğretim Teknolojileri ve Materyal & 4 & 7 & 3 & 4 & 5 & 4 \\
Tasarımı & & & & & & \\
D. Ölçme ve Değerlendirme & 6 & 3 & 4 & 6 & 6 & 5 \\
E. Sınıf Yönetimi & 7 & 5 & 5 & 5 & 5 & 5 \\
F. Okul Deneyimi & 7 & 6 & 7 & 5 & 7 & 6 \\
G. Özel Eğitim & 7 & 1 & 5 & 6 & 6 & 7 \\
H. Rehberlik & 7 & 5 & 8 & 7 & 8 & 7 \\
I. Öğretmenlik Uygulaması & 8 & 7 & 8 & 8 & 8 & 7 \\
İ. Türk Eğitim Sistemi ve Okul Yönetimi & 8 & 8 & 6 & 7 & 6 & 8 \\
\hline
\end{tabular}

Tablo 2'de bölümlere göre ders programında yer alan meslek bilgisi derslerini öğrencilerin aldıkları dönemler verilmiştir. Uygulama, dördüncü sinıf öğrencilerine yedinci dönem sonunda gerçekleştirildiğinden tabloda belirtilen derslerden tüm bölümlerin yedi dönem süresince aldıkları ortak yedi ders çalışmada kullanılmıştır. Bu dersler tabloda yer alan ilk yedi derstir. Bu derslere ek olarak öğrencilerin özelliklerini belirlemek amacıyla cinsiyet, 
bölüm bilgisi ve okuduğu üniversite de öğrencilere sorulmuştur. Cinsiyet ve okuduğu üniversite değişkenleri analiz sürecinde bağımsız değişkenler olarak ele alınmıştır.

\section{İşlem}

Meslek Bilgisi Derslerini Değerlendirme Formu, her iki üniversitede de yedinci dönem sonunda, katılıma gönüllü olan öğretmen adaylarına uygulanmıştır. Öğretmen adaylarından, geliştirilen "Meslek Bilgisi Derslerini Değerlendirme Formu"nda yer alan dersleri en önemli gördüklerine "1" sıra numarası verecek şekilde, "1-7" arası bir sıralama yapmaları istenmiştir. Öğretmen adayları, her bir ders için farklı bir sıra numaraları atamaları, farklı derslere aynı sıra numarası vermemeleri konusunda uyarılmıştır.

\section{Verilerin Analizi}

Verilerin analizinde yargıcı kararlarına dayalı ölçekleme yaklaşımlarından, sıralama yargıları kanunuyla ölçekleme yöntemi kullanılmıştır. Bu yöntemde öncelikle gözlemcilere $\mathrm{K}$ tane uyarıcının tümü verilir. Gözlemcilerden uyarıcıların tümünü düşünmesi ve her bir uyarıcıyı diğer uyarıcılarla karşılaştırarak bir sıra numarası vermesi istenir. $\mathrm{Bu}$ yolla uyarıcılar grubunun tümü, her bir uyarıcının karşılaştırıldığı bileşik bir standarda dönüştürülür. Uyarıcılara verilen sıralama yargılarından elde edilen oranlar bu bileşik standartla karşılaştırılarak ölçek değerleri elde edilir (Turgut ve Baykul, 1992).

Yargıların toplanması için öğrencilere aldıkları lisans meslek bilgisi dersleri, yedi uyarıcı (faktör) olarak verilmiştir. Öğrencilerden uyarıcıların tümünü düşünmeleri, öğretmen olduklarında meslek yaşamında önemli olma durumuna göre her bir uyarıcıyı diğer uyarıcılarla karşılaştırarak bir sıra numarası vermeleri istenmiştir. Bu şekilde elde edilen uyarıcılar, her bir uyarıcının karşılaştırıldığı bileşik bir standarda dönüştürülerek, uyarıcılara verilen sıralama yargılarından elde edilen oranlar bu bileşik standartla karşılaştırılmış ve ölçek değerleri elde edilmiştir. Veri toplama aracında yer alan yedi faktörün ölçek değerleri, incelenen tüm bağımsız değişkenler için ayrı ayrı Microsoft Excel programında çözümlenmiştir.

Ölçek değerlerinin elde edilmesinde kullanılan yargıların oluşturulmasında öğrencilerin dikkatli davranıp davranmadıklarının kontrol edilmesi için ölçek değerlerinin iç tutarlılık anlamında güvenirlik düzeyine bakılmıştır. Torgerson'e (1958) göre, ölçek değerlerinin iç tutarlılığının yoklanması, gözlenen frekanslardan elde edilen oranların $\left(\mathrm{p}_{\mathrm{jk}}\right)$ beklenen (teorik) oranlarla ( $\mathrm{p}_{\mathrm{jk}}^{\prime}$ ) ne dereceye kadar bağdaştığının belirlenmesi yoluyla yapılır (Akt. Turgut ve Baykul, 1992). Bu amaçla elde edilen ölçek değerlerinin ampirik verilere uygunluk derecesinin hesaplanması için teorik birim normal sapmalar matrisi, teorik oranlar matrisi ve ampirik oranlar ile teorik oranlar farkının mutlak değeri alınarak hatalar matrisi elde edilmiştir. Buna göre çalışmada yer alan yedi faktöre ilişkin hatalar matrisi, Tablo 3 'te verilmiştir.

Aşağıda verilen tabloda sütun toplamlarının toplamı bulunup tablodaki eleman sayısına $[\mathrm{K} .(\mathrm{K}-1) / 2=7.6 / 2=21]$ bölünerek ortalama hata hesaplanmıştır.

Hata: $\sum\left|p_{j k}-p^{1} j k\right|=7,199865$

Ortalama Hata: 7,199865/21=0,342851 
Tablo 3. Hatalar Matrisi $\left[P\left(\left|\mathrm{p}_{\mathrm{jk}}-\mathrm{p}_{\mathrm{jk}}^{1}\right|\right)\right]$

\begin{tabular}{lccccccc}
\cline { 2 - 8 } & $\mathrm{A}$ & $\mathrm{B}$ & $\mathrm{C}$ & $\mathrm{D}$ & $\mathrm{E}$ & $\mathrm{F}$ & $\mathrm{G}$ \\
\hline $\mathrm{A}$ & & & & & & & \\
B & 0,40967 & & & & & & \\
C & 0,183924 & 0,181719 & & & & & \\
D & 0,184557 & 0,094419 & 0,304179 & & & & \\
E & 0,410689 & 0,373609 & 0,591754 & 0,66675 & & & \\
F & 0,413793 & 0,35104 & 0,650753 & 0,716731 & 0,19622 & & \\
G & 0,141451 & 0,132774 & 0,47053 & 0,522566 & 0,122731 & 0,080007 & \\
\hline
\end{tabular}

Turgut ve Baykul'a (1992) göre ortalama hata değeri uyum derecesinin anlamlı olup olmadığı hakkında bilgi vermediğinden uyum derecesinin anlamlılığının test edilmesi için kikare istatistiği kullanılmıştır. Bu amaçla öncelikle, gözlenen oranlar matrisinden " $\mathrm{q}=$ arcsinp" dönüşümü yapılarak dönüştürülmüş oranlar matrisi elde edilmiştir. Bu matris yardımıyla elde edilen dönüştürülmüş teorik oranlar matrisiyle daha önce elde edilen dönüştürülmüş oranlar matrisinin farkı alınmıştır. Daha sonra farkların karesi hesaplanarak Tablo 4'de verilen dönüştürülmüş gözlenen ve teorik oranlar farklarının karesi matrisi $\left[\mathrm{P}\left(\mathrm{q}_{\mathrm{jk}}-\mathrm{q}_{\mathrm{jk}}{ }^{\prime}\right)^{2}\right]$ oluşturulmuştur.

Tablo 4. Dönüştürülmüş Gözlenen ve Teorik Oranlar Farklarının Karesi Matrisi $\left[P\left(q_{j k}-q_{j k}{ }^{\prime}\right)^{2}\right]$

\begin{tabular}{lllllll}
\hline A & B & C & D & E & F & G
\end{tabular}

\begin{tabular}{lllllll}
\hline A & & & & & & \\
B & 48,80 & & & & & \\
C & 94,48 & 66,81 & & & & \\
D & 53,89 & 174,60 & 82,67 & & & \\
E & 95,05 & 103,06 & 80,50 & 45,56 & & \\
F & 81,14 & 119,55 & 24,60 & 9,83 & 329,14 & \\
G & 173,20 & 148,15 & 3,35 & 1,65 & 107,44 & 224,04 \\
\hline
\end{tabular}

Toplam 2067, 532

Tablo 4'e göre, hesaplanan ki-kare değeri tablo değerini aştığından 15 serbestlik derecesinde ve 0,05 anlamlılık düzeyinde manidardır $\left(X^{2}=137,8355>X^{2}{ }_{\text {Tablo(15;0.05) }}=24,996\right)$. $\mathrm{Bu}$ durum, ölçeklemeye esas olan veriler, V. halin varsayımlarını veya ikili karşılaştırmalar yönteminin varsayımlarını veya bunların ikisini de sağlamadığı șeklinde yorumlanabilir. Kikare değerinin manidar olması yukarıdaki sebeplerden olabileceği gibi, ölçeklenen değişkenin tek boyutlu olmamasından da ileri gelebilir. Guilford (1954), bu gibi durumlarda III. halin kullanılmasını tavsiye etmektedir (Akt. Turgut ve Baykul, 1992). Bu nedenle, bu çalışmada da tam sıralama halinde ikili karşılaştırmalardan III. hale göre ölçekleme işlemi yapıllmıştır.

\section{BULGULAR}

$\mathrm{Bu}$ bölümde araştırmanın alt amaçlarına ilişkin bulgular ve bulgulara dayalı yorumlar alt amaçlardaki sıra ile verilmiştir.

\section{Sıralama Yargıları Kanunuyla Ölçekleme Yönteminden, Tüm Grup İçin Elde Edilen Ölçek Değerleri}

Araştırma kapsamında yer alan tüm öğrencilerin, meslek bilgisi derslerini önemli görme düzeylerine ilişkin ölçek değerleri Tablo 5 'te verilmiştir. 
Tablo 5. Öğrencilerin Meslek Bilgisi Derslerini Önemli Görme Durumlarına İlişkin Ölçek Dĕ̌erleri

\begin{tabular}{lcc}
\hline Faktörler & $\begin{array}{c}\text { Sira } \\
\text { Numarası }\end{array}$ & $\begin{array}{c}\text { Ölçek } \\
\text { Değerleri }\end{array}$ \\
\hline Okul Deneyimi & 1 & 0,000 \\
Sinıf Yönetimi & 2 & 0,104 \\
Öğretim İlke ve Yöntemleri & 3 & 0,233 \\
Eğitim Psikolojisi & 4 & 0,319 \\
Öğretim Teknolojileri ve Materyal Tasarımı & 5 & 0,910 \\
Ölçme ve Değerlendirme & 6 & 0,995 \\
Özel Eğitim & 7 & 1,023 \\
\hline
\end{tabular}

Tablo 5'e göre öğrencilerin meslek bilgisi derslerinde en önemli gördükleri ders "Okul Deneyimi" dersidir. Bu dersi sırasıyla, "Sınıf Yönetimi”, "Öğretim İlke ve Yöntemleri" ve "Eğitim Psikolojisi" dersleri izlemektedir. "Öğretim Teknolojileri ve Materyal Tasarımı" ve "Ölçme ve Değerlendirme" derslerinin ölçek değerleri arasındaki farkın az olduğu, son sırada ise "Özel Eğitim" dersinin yer aldığı görülmektedir.

\section{Sıralama Yargıları Kanunuyla Ölçekleme Yönteminden, Kadın Öğgrenciler İçin Elde Edilen Ölçek Değerleri}

Araştırma kapsamında yer alan kadın öğrencilerin, meslek bilgisi derslerini önemli görme düzeylerine ilişkin ölçek değerleri Tablo 6'da verilmiştir.

Tablo 6. Kadın Öğrencilerin Meslek Bilgisi Derslerini Önemli Görme Durumlarına İlişkin Ölçek Dĕgerleri

\begin{tabular}{lcc}
\hline Faktörler & $\begin{array}{c}\text { Sira } \\
\text { Numarası }\end{array}$ & $\begin{array}{c}\text { Ölçek } \\
\text { Değerleri }\end{array}$ \\
\hline Sınıf Yönetimi & 1 & 0,000 \\
Okul Deneyimi & 2 & 0,014 \\
Öğretim İlke ve Yöntemleri & 3 & 0,235 \\
Eğitim Psikolojisi & 4 & 0,352 \\
Ölçme ve Değerlendirme & 5 & 0,991 \\
Özel Eğitim & 6 & 0,993 \\
Öğretim Teknolojileri ve Materyal Tasarımı & 7 & 1,011 \\
\hline
\end{tabular}

Tablo 6’ya göre kadın öğrencilerin meslek bilgisi derslerinden en önemli gördükleri ders, "Sınıf Yönetimi" dersidir. Bu dersi sırasıyla, "Okul Deneyimi”, "Öğretim İlke ve Yöntemleri" ve "Eğitim Psikolojisi" dersleri izlemektedir. "Ölçme ve Değerlendirme" ve "Özel Eğitim" derslerinin ölçek değerleri arasındaki farkın az olduğu, son sırada ise "Öğretim Teknolojileri ve Materyal Tasarımı” dersinin yer aldığg görülmektedir.

\section{Sıralama Yargıları Kanunuyla Ölçekleme Yönteminden, Erkek Öğrenciler İçin Elde Edilen} Ölçek Değerleri

Araştırma kapsamında yer alan erkek öğrencilerin, meslek bilgisi derslerini önemli görme düzeylerine ilişkin ölçek değerleri Tablo 7'de verilmiştir. 
Tablo 7. Erkek Öğrencilerin Meslek Bilgisi Derslerini Önemli Görme Durumlarına İlişkin Ölçek Değerleri

\begin{tabular}{lcc}
\hline Faktörler & $\begin{array}{c}\text { Sira } \\
\text { Numarası }\end{array}$ & $\begin{array}{c}\text { Ölçek } \\
\text { Değerleri }\end{array}$ \\
\hline Okul Deneyimi & 1 & 0,000 \\
Öğretim İlke ve Yöntemleri & 2 & 0,114 \\
Eğitim Psikolojisi & 3 & 0,125 \\
Sınıf Yönetimi & 4 & 0,306 \\
Özel Eğitim & 5 & 0,612 \\
Öğretim Teknolojileri ve Materyal Tasarımı & 6 & 0,685 \\
Ölçme ve Değerlendirme & 7 & 1,017 \\
\hline
\end{tabular}

Tablo 7'ye göre erkek öğrencilerin meslek bilgisi derslerinde en önemli gördükleri ders "Okul Deneyimi” dersidir. Bu dersi surasıyla, "Öğretim İlke ve Yöntemleri”, "Eğitim Psikolojisi" ve "Sınıf Yönetimi" dersleri izlemektedir. Son sırada ise farklı olarak "Ölçme ve Değerlendirme" dersinin yer aldığ 1 görülmektedir. "Öğretim İlke ve Yöntemleri" ve "Eğitim Psikolojisi” derslerinin ölçek değerlerinin oldukça yakın olduğu görülmektedir.

Cinsiyete göre öğrencilerin meslek bilgisi dersleri hakkındaki görüşleri arasında farklılık olduğu görülmektedir. Yapılan ölçekleme işlemleri sonucunda, kadın ve erkek öğrenciler için elde edilen ölçek değerleri arasındaki tutarlığı incelemek için hesaplanan Spearman rho (rs) korelasyon katsayısı 0.68 olarak bulunmuş, ancak ilişki manidar çıkmamıştır ( $p>05)$. Bu sonuç öğrencilerin görüşleri arasında cinsiyete göre farklılık olduğunu desteklemektedir.

\section{Sıralama Yargıları Kanunuyla Ölçekleme Yönteminden, Ankara Üniversitesi Öğrencileri İçin Elde Edilen Ölçek Dĕ̆erleri}

Araştırma kapsamında yer alan Ankara Üniversitesi öğrencilerinin, meslek bilgisi derslerini önemli görme düzeylerine ilişkin ölçek değerleri Tablo 8'de verilmiştir.

Tablo 8. Ankara Üniversitesi Öğrencilerin Meslek Bilgisi Derslerini Önemli Görme Durumlarına İlişkin Ölçek Değerleri

\begin{tabular}{lcc}
\hline Faktörler & $\begin{array}{c}\text { Sıra } \\
\text { Numarası }\end{array}$ & $\begin{array}{c}\text { Ölçek } \\
\text { Değerleri }\end{array}$ \\
\hline Sınıf Yönetimi & 1 & 0,000 \\
Okul Deneyimi & 2 & 0,011 \\
Öğretim İlke ve Yöntemleri & 3 & 0,525 \\
Eğitim Psikolojisi & 4 & 0,534 \\
Özel Eğitim & 5 & 0,635 \\
Ölçme ve Değerlendirme & 6 & 0,912 \\
Öğretim Teknolojileri ve Materyal Tasarımı & 7 & 1,338 \\
\hline
\end{tabular}

Tablo 8 incelendiğinde Ankara Üniversitesi öğrencilerine göre meslek bilgisi derslerinden en önemlisi "Sınıf Yönetimi" olarak çıkmıştır. Bu dersten sonra ikinci sırayı "Okul Deneyimi" dersi almaktadır. Ancak ilk iki ders arasında çok küçük bir fark vardır. Daha sonra sırasıyla "Öğretim İlke ve Yöntemleri”, "Eğitim Psikolojisi”, “Özel Eğitim”, "Ölçme ve Değerlendirme" ve "Öğretim Teknolojileri ve Materyal Tasarımı" dersleri takip etmektedir. 


\section{Sıralama Yargıları Kanunuyla Ölçekleme Yönteminden, Recep Tayyip Erdoğan Üniversitesi Öğrencileri İçin Elde Edilen Ölçek Değerleri}

Araştırma kapsamında yer alan Recep Tayyip Erdoğan Üniversitesi öğrencilerinin, meslek bilgisi derslerini önemli görme düzeylerine ilişkin ölçek değerleri Tablo 9'da verilmiştir.

Tablo 9. Recep Tayyip Erdoğan Üniversitesi Öğrencilerin Meslek Bilgisi Derslerini Önemli Görme Durumlarına İlişkin Ölçek Değerleri

\begin{tabular}{lcc}
\hline Faktörler & $\begin{array}{c}\text { Sura } \\
\text { Numaras1 }\end{array}$ & $\begin{array}{c}\text { Ölçek } \\
\text { Değerleri }\end{array}$ \\
\hline Okul Deneyimi & 1 & 0,000 \\
Öğretim İlke ve Yöntemleri & 2 & 0,041 \\
Eğitim Psikolojisi & 3 & 0,165 \\
Sinıf Yönetimi & 4 & 0,259 \\
Öğretim Teknolojileri ve Materyal Tasarımı & 5 & 0,732 \\
Özel Eğitim & 6 & 1,189 \\
Ölçme ve Değerlendirme & 7 & 1,225 \\
\hline
\end{tabular}

Tablo 9 incelendiğinde Recep Tayyip Erdoğan Üniversitesi öğrencilerine göre meslek bilgisi derslerinden en önemlisi "Okul Deneyimi”" dersidir. Bunu sırasıyla "Öğretim İlke ve Yöntemleri”, "Eğitim Psikolojisi”, "Sınıf Yönetimi”, “Öğretim Teknolojileri ve Materyal Tasarımı", "Özel Eğitim" ve "Ölçme ve Değerlendirme" dersleri takip etmektedir.

Üniversitelere göre öğrencilerin meslek bilgisi dersleri hakkındaki görüşleri arasında farklılık olduğu görülmektedir. Yapılan ölçekleme işlemleri sonucunda, Ankara ve Recep Tayyip Erdoğan üniversitelerindeki öğrenciler için elde edilen ölçek değerleri arasındaki tutarlığı incelemek için hesaplanan Spearman rho (rs) korelasyon katsayısı 0.68 olarak bulunmuş, ancak ilişki manidar çıkmamıştır ( $\mathrm{p}>.05)$. Bu sonuç öğrencilerin görüşleri arasında üniversitelere göre farklılık olduğunu desteklemektedir.

\section{SONUÇLAR ve TARTIŞMA}

Yapılan bu araştırmada, Ankara Üniversitesi Eğitim Bilimleri Fakültesi ve Recep Tayyip Erdoğan Üniversitesi Eğitim Fakültesi'nde eğitim gören son sınıf öğrencilerinin meslek bilgisi derslerini algıladıkları önem sırasına göre ölçeklenmesi amaçlanmıştır. Bu amaçla, veriler V. halin varsayımlarını sağlamadığı için tam sıralama halinde ikili karşılaştırmalardan III. hale göre ölçekleme işlemi yapılmıştır. Yapılan ölçekleme işlemi sonunda, öğrencilerin en önemli gördükleri ders "Okul Deneyimi", en az önemli gördükleri ders ise "Özel Eğitim" çıkmıştır. Bunun dışında öğrencilerin cinsiyetine göre yapılan ölçeklemede kadın öğrencilerin en önemli gördükleri ders "Sınıf Yönetimi", en az önemli gördükleri ders "Öğretim Teknolojileri ve Materyal Tasarımı"; erkek öğrencilerin en önemli gördükleri ders "Okul Deneyimi", en az önemli gördükleri ders "Ölçme ve Değerlendirme" çıkmıştır. Üniversite değişkeni ele alındığında ise Ankara Üniversitesi Eğitim Bilimleri Fakültesi öğrencilerinin en önemli gördükleri ders "Sınıf Yönetimi”, en az önemli gördükleri ders "Öğretim Teknolojileri ve Materyal Tasarımı”; Recep Tayyip Erdoğan Üniversitesi Eğitim Fakültesi öğrencilerinin en önemli gördükleri ders "Okul Deneyimi”, en az önemli gördükleri ders "Ölçme ve Değerlendirme" olarak bulunmuştur.

Araştırma sonunda değişkenlere göre elde edilen ölçek değerlerine bakıldığında, neredeyse tüm değişkenler için "Okul Deneyimi” dersinin en önemli olduğu, sonrasında 
"Sınıf Yönetimi” dersinin izlediği görülmektedir. Öğrencilerden aldıkları meslek bilgisi derslerini öğretmen olduklarında önemli olma durumlarına göre sıralamaları istendiğinden "Okul Deneyimi" dersinin ilk sıralarda yer alması beklenen bir durumdur. Taşkın ve Hacıömeroğlu'nun (2010) yaptığı araştırmada bu sonucu desteklemektedir. Araştırmalarında öğretmen adaylarının staj gerektiren meslek bilgisi derslerini diğer meslek bilgisi derslerinden ayrı olarak değerlendirdikleri ve bu derslerin önemini vurguladıkları görülmüştür. Şirin ve Cesur (2008) yaptıkları araştırma sonucunda, öğretmen adaylarının meslek bilgisi derslerinde teorik kısımların uygulamada nasıl kullanıldığına yönelik etkinliklere daha çok yer verilmesi durumunda, teori ile uygulama arasındaki bağın güçleneceğini düşündüklerini ifade etmişlerdir.

“Öğretim Teknolojileri ve Materyal Tasarımı", “Ölçme ve Değerlendirme” ve "Özel Eğitim" dersleri ise genellikle son sıralara konulmuştur. Bu derslerin son sıralarda yer alması, öğrencilerin diğer derslere göre daha az önemli görmelerinden kaynaklanabileceği gibi, YÖK tarafından belirlenen ders içeriğinin kapsamı ve/veya dersi veren öğretim elemanının dersin öğrencilerin meslek yaşamlarındaki önemini yeterince hissettirmemelerinden de ve/veya dersin etkili ve verimli işlenmemesinden de kaynaklanabilir. Yüksel (2009), meslek bilgisi derslerinin öğretmen yetiştirme programlarında yer alması kadar, etkili ve verimli bir şekilde işlenmesinin de adaylara öğretmenlik bilgi ve becerisi kazandırmada ve mesleğe ilişkin olumlu tutum geliştirmelerinde önemli olduğunu ifade etmiştir. Öğrencilerin yaptıkları sıralamalarda, hangi değişken/değişkenlerin etkili olduğu öğrencilerle yapılacak görüşmelerle desteklenirse bu bağlamda yer alan lisans meslek bilgisi derslerinin gerekliliği hakkında çıkarımda bulunula bilinir.

\section{KAYNAKLAR}

Acar Güvendir, M. ve Özer Özkan, Y. (2013). İki ölçekleme yönteminin karşılaştırılması: İkili karşılaştırma ve sıralama yargıları. Ĕ̈itim Bilimleri Araştırmaları Dergisi, 3(1), 105-119.

Albayrak, A. ve Gelbal, S. (2012, Eylül). İkili karşılaştırmalar yargılarına ve sıralama yargılarına dayalı ölçekleme yaklaşımlarından elde edilen ölçek değerlerinin tutarlı̆̆ının karşılaştırılması. 21. Ulusal Eğitim Bilimleri Kongresi’nde sunulan bildiri. Marmara Üniversitesi, İstanbul.

Altun, A. ve Gelbal, S. (2014). Öğretmenlerinin kullandıkları ölçme ve değerlendirme yöntem veya araçlarının ikili karşılaştırma yöntemiyle belirlenmesi. Ĕ̆itimde ve Psikolojide Ölçme ve Dĕ̆erlendirme Dergisi, 5(1), 1 -11.

Anıl, D. ve Güler, N. (2006). İkili karşılaştırma yöntemiyle ölçekleme çalışmasına bir örnek. Hacettepe Üniversitesi Ĕ̈itim Fakültesi Dergisi, 30, 30-36.

Bal, Ö. (2011). Seviye belirleme sınavı (SBS) başarısında etkili olduğu düşünülen faktörlerin sıralama yargıları kanunuyla ölçeklenmesi. Eğitimde ve Psikolojide Ölçme ve Değerlendirme Dergisi, 2(2), 200-209.

Bülbül, T. and Acar, M. (2012). A pair-wise scaling study on the missions of education supervisors in Turkey. International Journal of Human Sciences, 9(2), 623-640.

Ekici, G. (2008). Öğretmen adaylarının öğretmenlik meslek bilgisi derslerine yönelik tutumları ile öğrenme biçimlerinin değerlendirilmesi. Yüzüncü Yıl Üniversitesi Eğitim Fakültesi Dergisi, 5(1), 111-132.

Kara, Y. ve Gelbal, S. (2013). İlköğretim öğrencilerinin başarılarını etkileyen özelliklerin tam sıralama halinde ikili karşılaştırmalar yöntemiyle ölçeklenmesi. Eğitimde ve Psikolojide Ölçme ve Değerlendirme Dergisi, 4(1), 33-51.

Karasar, N. (2007). Bilimsel araştırma yöntemi (17. Baskı). Ankara: Nobel Yayın Dağıtım.

Kart, A. ve Gelbal, S. (2014). Öğretmen adaylarının bilimsel araştırma öz yeterlik algılarının ikili karşılaştırmalı yargılar yöntemiyle belirlenmesi. Eğitimde ve Psikolojide Ölçme ve Değerlendirme Dergisi, 5(1), 12 23.

Küçükahmet, L. (1993). Öğretmen yetiştirme (programları ve uygulamaları). Ankara: Gazi Üniversitesi İletişim Fakültesi Matbaasl.

Küçükahmet, L. (2007). 2006-2007 Öğretim yılında uygulanmaya başlayan öğretmen yetiştirme lisans programlarının değerlendirilmesi. Türk Ĕ̈itim Bilimleri Dergisi, 5 (2), 203-218.

Nartgün, Z. (2006). Öğretmenlik meslek bilgisi derslerinin önem düzeyinin ikili karşılaştırmalarla ölçeklenmesi. A.I.B.̈̈. Ë̆itim Fakültesi Dergisi, 6(2), 161-176.

Özer, Y. ve Acar, M. (2011). Öğretmenlik mesleği genel yeterlikleri üzerine ikili karşılaştırma yöntemiyle bir ölçekleme çalışması. Çukurova Üniversitesi Eğitim Fakültesi Dergisi, 3(40), 89-101. 
Öztürk, N., Özdemir, S. ve Gelbal, S. (2011, Eylül). İki farkl ölçekleme yaklaşımından elde edilen ölçek değerleri tutarlılığının incelenmesi. 20. Ulusal Eğitim Bilimleri Kurultayı’nda sunulan bildiri. Mehmet Akif Ersoy Üniversitesi, Burdur.

Polat, B. ve Göksel, Ç. H. (2014). Öğretmen adaylarının sosyal aktivite tercihlerinin ikili karşılaştırmalı ölçekleme yöntemiyle belirlenmesi. Eğitimde ve Psikolojide Ölçme ve Değerlendirme Dergisi, 5(1), 88100.

Sılay, İ. ve Gök, S. (2004, Temmuz). Öğretmen adaylarının uygulama okullarında karşılaştıkları sorunlar ve bu sorunları gidermek amacıyla hazırlanan öneriler üzerine bir çalışma. XIII. Ulusal Eğitim Bilimleri Kurultayı'nda sunulan bildiri. İnönü Üniversitesi, Malatya.

Şirin, E. F. ve Cesur, K. (2008). Beden eğitimi öğretmen adaylarının alan bilgisi ve öğretmenlik meslek dersleri ile öğretmenlik uygulaması dersi başarıları arasındaki ilişki. Selçuk Üniversitesi Beden Eğitimi ve Spor Bilim Dergisi, 10 (1), 1-10.

Şişman, M. (2001). Öğretmenliğe giriş. Ankara: Pegem Akademi Yayıncılık.

Şişman, M. ve Acat, M. B. (2003). Öğretmenlik uygulaması çalışmalarının öğretmenlik mesleğinin algılanmasındaki etkisi. Firat Üniversitesi Sosyal Bilimler Dergisi, 13(1), 235-250.

Taşkın, Ç. Ş. ve Hacıömeroğlu, G. (2010). Meslek bilgisi derslerinin öğretmen adaylarının profesyonel gelişimindeki önemi. Pamukkale Üniversitesi Ĕgitim Fakültesi Dergisi, 28, 165-174.

Torgerson, W. S. (1958). Theory and methods of scaling. Newyork: John Wiley \& Sons Inc.

Turgut, M. F. ve Baykul, Y. (1992). Ölçekleme teknikleri. Ankara: ÖSYM Yayınları.

Varış, F. (1973). Ögretmen yetiştirme üzerine. 50. ylla armağan. Ankara: Ankara Üniversitesi Eğitim Fakültesi Yayını.

Yüksek Öğretim Kurumu (2007). Öğretmen yetiştirme ve eğitim fakülteleri (1982-2007). Ankara: Meteksan A.Ş.

Yüksel, S. (2009). Eğitim Fakültesi öğrencilerinin öğretmenlik meslek bilgisi derslerine ilişkin görüşleri, Ankara Üniversitesi Eğitim Fakültesi Dergisi, 42(1), 435-455.

\section{EXTENDED ABSTRACT}

\section{Introduction}

In order to be a qualified teacher, teacher candidates studying in faculties of education have to take general culture, knowledge of subject area and pedagogy courses. Şişman (2001) states that the knowledge, skills and qualifications necessary for teachers in teaching and learning process should be acquired before starting service. Curriculums of the faculties of education and especially pedagogy courses have a significant role in teacher candidates' becoming qualified teachers by fulfilling their professional development. Pedagogy courses aim to develop specific behaviors related with the teaching profession. For this reason, determining teacher candidates' views on the importance of pedagogy courses determined by YÖK (Higher Education Committee) is thought to be necessary. The aim of this study is to determine which pedagogy courses taken until eight semesters are thought to be more important by fourth grade students studying in faculties of education.

\section{Method}

As it is aimed to define preexisting condition, this study is a survey design. According to this aim, participants were asked to give point to the courses in the "Assessment Form of Pedagogy Courses" developed by the researchers from 1 to 7 as the most important one would be 1 . For data analysis, the law of rank order judgment scaling model has been used. The law of rank order judgment scaling model, is sorting stimulants according to a certain quality in order from high to low or low to high and to give each of them an ordinal number according to its place in the sorting. Scale values of seven factors which are in data collection tool are analyzed with Microsoft Excel program separately for all independent variables. In order to control whether students acted carefully in creating judgments which were used in gathering scale values, reliability level is investigated by means of internal consistency of scale values. 


\section{Results and Discussion}

Apart from this, according to scaling which is done according to gender of students, it is seen that female students find "Classroom Management" course most important and "Teaching Technologies and Material Design" course least important; male students find "School Experience" course most important and "Measurement and Evaluation" course least. When it comes to deal with school variable, it is seen that Ankara University Faculty of Educational Sciences students find "Classroom Management" course most important and "Teaching Technologies and Material Design" course least important; Recep Tayyip Erdoğan University Faculty of Education students find "School Experience" course most important and "Measurement and Evaluation" course least important.

Considering scale values which were gathered according to the variables at the end of the research, it is seen that for almost all variables, "School Experience" course is the most important and followed by "Classroom Management" course. It is expected to see "School Experience" course to take place near the top as they are asked to sort according to the state of importance of pedagogy courses when that become teachers. Taşkın and Haciömeroğlu's (2010) research also supports this result. In their research it is seen that teacher candidates evaluate pedagogy courses which require internship differently from other pedagogy courses, and they put emphasis on the importance of these courses. "Teaching Technologies and Material Design", "Measurement and Evaluation" and "Special Education" courses are usually sorted in lower lines. These lessons' taking place in lower ranks may be as a result of students' considering them as less important, as well as the extent of lesson content which is determined by YÖK and/or lecturer's lack of making students feel the importance of the courses in their career and/or teaching lessons ineffectively and inefficiently. Yüksel (2009) states that it is as important to have pedagogy courses in teacher training programs as teaching lessons effectively and efficiently in providing candidate teachers teaching information and ability and developing a positive attitude towards profession. In the sorting that students made, deductions can be made about the necessity of license pedagogy courses in this sense, if the meetings to be held with students support which variable(s) are effective. 